\title{
Comparison of Viable Units Counts of BCG Vaccines on Four Different Culture Media
}

\author{
Sang Jae Kim, Gill Han Bai, Seung Ho Lee, and Keum Ja Lee \\ Korean Institute of Tuberculosis, Korean National TB Association, Seoul, Korea
}

=국문초록 $=$

$\mathrm{BCG}$ 생균수 검사방법의 개선에 관한 연구

대한결핵협회 결핵연구원

김상재·배길한·이승호·이금자

\begin{abstract}
BCG vaccine 의 생산과, 접 종을 목적으로 현지에서 보관증인 vaccine 의 품질관리에 있어서는 vaccine 의 생균수 측정이 vaccine 평가시의 중요 수단의 하나로 이용되고 있다. 세계보건기구의 추천에 의해 현재까지는 Löwenstein-Jensen(L-J)배지를 BCG 생균수 검사에 사용해왔으나 L-J 배지는 배지 상의 생균수와 배지간의 변이가 심하여 다양한 결과를 얻는 경우가 많았다. 따라서, L-J 외의 기존 결핵균용 배지와 균집락형성 양상을 비교 관찰하여 생균수 검사에 더 적합한 배지를 선정코자 본 시 험을 실시하였다.

시험결과에 의하면, 현재 널리 사용되고 있는 L-J 배지가 비교 시험된 KIT, $1 \%$ Ogawa, Middlebrook $7 \mathrm{H} \mathrm{11}$ 배지에 비해, 백신 균주나 제품에 관계없이 발육한 균집락수도 떨어질 뿐 아니라 발육 속도도 느렸다. 그러므로 앞으로의 BCG 생균수 검사에서는 $\mathrm{KIT}$ 배지나 $1 \%$ Ogawa 배지를 사용함이 더욱 경제적이고도 적합할 것으로 생각되었다.
\end{abstract}

\section{INTRODUCTION}

Despite the long controversy over its effectiveness, BCG vaccination remains an important component of national tuberculosis control programme in many developing countries and in some developed countries. BCG vaccination has been practiced since early 1950 s in Korea so that well over $80 \%$ of people aged less than 30 years have been vaccinated as it was revealed in 1985 survey.

Determination of viable units in BCG vaccines is an utmost important control measure not only for production but also for storage status in the fields prior to use. The Löwenstein-Jensen medium has been most widely used to determine viable particles in BCG vaccines in many countries including Korea. However we often observed a significant variation in viable units counts between replicate slants and sometimes it took more than 4 weeks incubation to obtain maximum counts of viable units even if $\mathrm{WHO}$ technical report series recommended 4 weeks incubation at $37^{\circ} \mathrm{C}$.

In this study, four different culture media have been compared to count viable units in BCG vaccines and the results are presented in this paper.

\section{MATERIALS AND METHODS}

Vaccines: Three different vaccine products have been used in this study. Domestic BCG vaccines 
Table 1. Formula of Three Egg-based Media Used in This Study

\begin{tabular}{|c|c|c|c|c|}
\hline Ingredients & dium & L-J & $1 \%$ Ogawa & $\mathrm{KIT}$ \\
\hline \multirow{8}{*}{ Basal medium } & $\left(\mathrm{KH}_{2} \mathrm{PO}_{4}\right.$ & $0.4 \%$ & $1.0 \%$ & $2.7 \%$ \\
\hline & $\mathrm{Na}_{2} \mathrm{HPO}_{4}$ & & & $1.0 \%$ \\
\hline & Sodium glutamate & & $1.0 \%$ & $0.9 \%$ \\
\hline & $\mathrm{MgSO}_{4} \cdot 7 \mathrm{H}_{2} \mathrm{O}$ & $0.04 \%$ & & \\
\hline & Magnesium citrate & $0.1 \%$ & & \\
\hline & Asparagine & $0.6 \%$ & & \\
\hline & Pyruvic acid & & & $0.1 \%$ \\
\hline & Distilled water & $1,000 \mathrm{ml}$ & $1,000 \mathrm{ml}$ & $1,000 \mathrm{ml}$ \\
\hline \multicolumn{2}{|c|}{ Whole egg homogenate } & $1,667 \mathrm{ml}$ & $2,000 \mathrm{ml}$ & $2,000 \mathrm{ml}$ \\
\hline \multicolumn{2}{|c|}{$2 \%$ malachite green } & $33.3 \mathrm{ml}$ & $60 \mathrm{ml}$ & $60 \mathrm{ml}$ \\
\hline \multicolumn{2}{|l|}{ Glycerine } & $20 \mathrm{ml}$ & $60 \mathrm{ml}$ & $40 \mathrm{ml}$ \\
\hline
\end{tabular}

(Lot No. 85-1) were produced with French strain 1173-p2 and contained $1 \mathrm{mg}$ of bacilli per $\mathrm{ml}$. One of the imported vaccnies was also produced with French strain 1173-p 2, but the strain of the other one was Tokyo 172. Bacterial contents of both imported vaccines were $0.5 \mathrm{mg}$ fer $\mathrm{ml}$ and their lot numbers were $\mathrm{F} £ 004 \mathrm{M}$ and $220 \mathrm{~L}$. Seven ampoules of each freeze-dried vaccines kept at $4^{\circ} \mathrm{C}$ were used to heat stability tests. Fourteen ampoules ( 9 ampoules of domestic vaccine and 5 ampoules of imported vaccine) were collected from the peripheral health centers where the health workers kept for vaccination, and incluced in this study.

Media: Four different culture media were used in this study. Three egg-based media are Löwenstein-Jensen medium without potato starch, 1\% $\mathrm{KH}_{2} \mathrm{PO}_{4}$ Ogawa medium, and $\mathrm{KIT}$ (Korean Institute of Tuberculosis) medium, which formulas are shown in Table 1. Agar based $7 \mathrm{H} 11$ medium was also used and the medium was dispensed into petri-dishes instead of test tubes.

Determination of viable units in BCG vaccines: Vaccine ampoule was reconstituted with Sauton's broth medium(1/4 strength) and diluted to 10,000, 20,000, and 40,000 folds prior to inoculate onto media. Parts of vaccines tested were kept at $4^{\circ} \mathrm{C}$ and $37^{\circ} \mathrm{C}$ and their viable units counted after 1 and 6 weeks treatment. Viable units in vaccine ampoules from the health centers were determined without heat $\left(37^{\circ} \mathrm{C}\right)$ treatment. $0.1 \mathrm{ml}$ of each dilution was inoculated onto 10 or 20 slopes or plates of each medium according to dilutions, then seeded egg-based media were incubated at $37^{\circ} \mathrm{C}$ in an ordinary hot room, while seeded agarbased media ( $7 \mathrm{H} 11$ agar) were incubated in a $\mathrm{CO} 2$ (10\% pressure)-incubator. The growth appearance has been observed every week after two weeks incubation until maximum counts attained. Viable numbers of each BCG strain were calculated by WHO recommendation.

\section{RESULTS}

Of the four different culture media compared, colony appearance of BCG has been delayed much longer on the L-J medium than on the other media. As seen in Table 2, the maximum number of viable particles were obtained with 4 out of 21 vaccine ampoules after 5 weeks incubation on the L-J medium and the remaining 17 ampoules after 6 weeks incubation, while 10 to 11 vaccine ampoules yielded maximum counts after 3 weeks incubation on the other medium.

The growth of BCG was much faster on $1 \%$ Ogawa, KIT, and $7 \mathrm{H} 11$ media, thus beyond 4 weeks some colonies coalesced thereby resulting 
Table 2. Comparison of Incubation Times to Attain Maximum Counts of Viable Units in BCG Vaccines on Different Culture Media

\begin{tabular}{lccccc}
\hline \hline \multirow{2}{*}{ Culture media } & $\begin{array}{c}\text { Total number of } \\
\text { vaccine ampoules } \\
\text { tested }\end{array}$ & 3 & 4 & Incubation & times(waeks) \\
\cline { 2 - 5 } & 21 & 0 & 0 & 5 & 6 \\
\hline L-J medium & 21 & 10 & 11 & - & 17 \\
1\% Ogawa medium & 21 & 11 & 10 & - & - \\
KIT medium & 21 & 10 & 11 & - & - \\
7 H1l medium & & & &
\end{tabular}

Table 3. Viable Units Counts in Three Products of Vaccines on the Four Different Culture Media

\begin{tabular}{lccc}
\hline \multirow{2}{*}{ Vaccine strain** } & \multicolumn{2}{c}{ French $1173-\mathrm{p} 2$} & \multirow{2}{*}{$\begin{array}{c}\text { Tokyo-172 } \\
220 \mathrm{~L}\end{array}$} \\
\cline { 2 - 3 } & $85-1$ & $\mathrm{~F} 5004 \mathrm{M}$ & $0.5 \mathrm{mg} / \mathrm{ml}$ \\
\hline Bacterial content & $1 \mathrm{mg} / \mathrm{ml}$ & $0.5 \mathrm{mg} / \mathrm{ml}$ & \\
\hline Culture media* & & & $6.84 \pm 0.09$ \\
L-J medium & $5.72 \pm 0.16$ & $5.96 \pm 0.10$ & $6.96 \pm 0.07$ \\
$1 \%$ Ogawa medium & $6.37 \pm 0.13$ & $6.22 \pm 0.04$ & $7.02 \pm 0.05$ \\
KIT medium & $6.36 \pm 0.08$ & $6.24 \pm 0.14$ & $7.10 \pm 0.09$ \\
7H1l medium & $6.30 \pm 0.12$ & $6.27 \pm 0.09$ & \\
\hline
\end{tabular}

Four ampoules of each vaccine have been tested. Numbers of viable particles are expressed in mean (log number) and standard deviation.
Between BCG products
$* * \mathrm{~F}=56.60$
F. 99(3.6) $=9.78$
WWithin media used
$* \mathrm{~F}=6.659$
F. 95(2.6) $=5.14$

in reduction of colony counts.

The viable units counts were also very significantly less on the L-J medium than on the other media as seen in Table $3(\mathrm{P}<0.01)$. Mean $\log$ number of viable units in two French strain 1173-p2 were 5.72 and 5.96 respectively on the L-J medium, but more than 6.30 and 6.22 on the other media. Viability of bacilli in Lot No. F5004 $\mathrm{M}$ and $220 \mathrm{~L}$ vaccine seemed to be superior to Lot No. 85-1 vaccine because viable units counts of the former were almost same with those of the latter even if bacterial contents of the former were merely half of the latter. Tokyo strain vaccine also grew better on $1 \%$ Ogawa, KIT, and $7 \mathrm{H} 11$ media, however difference in viable counts between L-J and the other media was less remarkable than French strain vaccine.

Heat $\left(37^{\circ} \mathrm{C}\right)$ treatment lowered viable units counts in all tested vaccines, however decrease of viable counts was much more drastic in the $85-1$

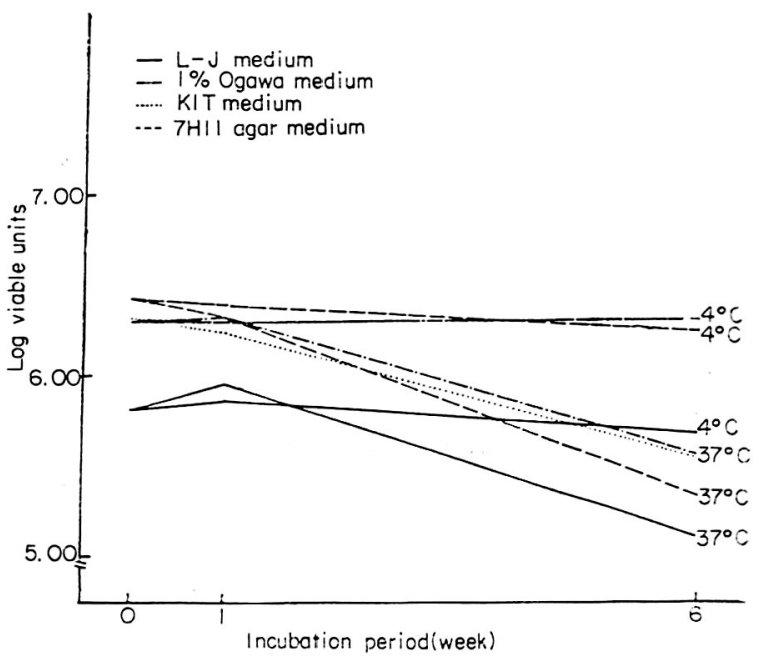

Fig. 1. Heat $\left(37^{\circ} \mathrm{C}\right)$ Stability of Lot No. $85-1$ French Strain 1173-p 2 Vaccine.

than in two others as shown in Figures 1,2 , and 3. Merely $0.5 \sim 5.0 \%$ or $2.0 \sim 4.0 \%$ of viable counts have been reduced in French strain 1173-p2 and 
Table 4. Viable Units Counts in Vaccines Collected from Health Centers

\begin{tabular}{lccc}
\hline $\begin{array}{c}\text { Name of health centers } \\
\text { from which vaccines } \\
\text { were collected }\end{array}$ & $\begin{array}{c}\text { Lot } \\
\text { No. }\end{array}$ & & $\begin{array}{c}\text { Viable units counts } \\
\text { expres in Log. }\end{array}$ \\
\hline Gudium & $\begin{array}{c}\text { KIT } \\
\text { medium }\end{array}$ \\
Buahn, Chun-buk & $83-4$ & 0 & 6.68 \\
Sungbuk, Seoul & $83-10$ & 6.47 & 6.63 \\
Choong-gu, Seoul & $83-10$ & 6.76 & 6.85 \\
Yongsan, Seoul & $83-10$ & 6.04 & 6.46 \\
Chongro, Seoul & $83-13$ & 6.30 & 6.66 \\
Kangso, Seoul & $84-1$ & 6.76 & 7.00 \\
Dongjak, Seoul & $84-1$ & 6.57 & 6.90 \\
Youngdeungpo, Seoul & $84-1$ & 6.42 & 6.94 \\
Mapo, Seoul & F 2003M & 6.68 & 6.86 \\
Pusan & F2003M & 6.25 & 6.72 \\
Eunpyung, Seoul & F2004M & 6.68 & 6.85 \\
Seoul & F2004M & 6.47 & 6.67 \\
Seoul & F2004M & 6.30 & 6.75 \\
\hline
\end{tabular}

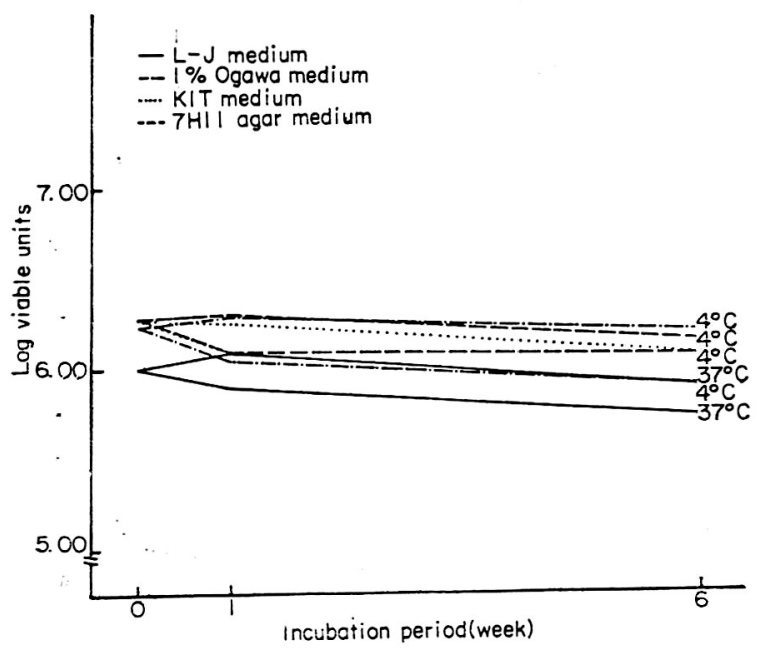

Fig. 2. Heat $\left(37^{\circ} \mathrm{C}\right)$ Stability of Lot No. F5004M French Strain 1173-p2 Vaccine.

Tokyo-172 strain vaccines by $37^{\circ} \mathrm{C}$ incubation for 6 weeks, while $10.0 \sim 15.0 \%$ reduction have been noticed in Lot No. 85-1 French strain 1173-p2 vaccine.

BCG vaccines collected from health centers also showed less viable units counts on the L-J medium than on the KIT medium. Most viable

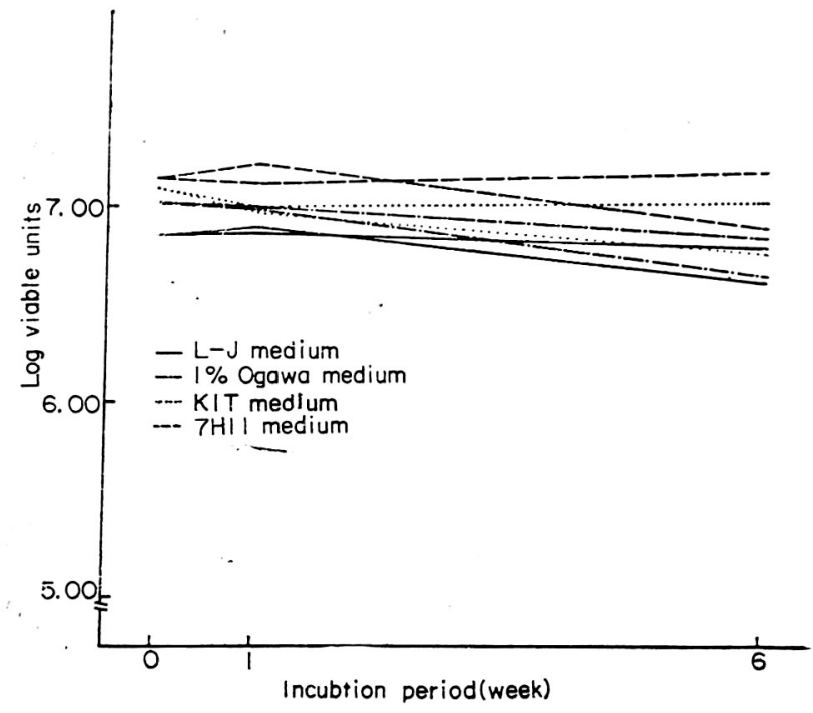

Fig. 3. Heat $\left(37^{\circ} \mathrm{C}\right)$ Stability of Lot No. $22 \mathrm{OL}$ Tokyo-172 Strain Vaccine.

counts of tested vaccine ampoules obtained on the KIT medium were more than double of those on the L-J medium.

\section{DISCUSSION}

Viable units counts of $B C G$ vaccines have long been carried out as a control measure for both production and storage status of vaccines in the fields. Therefore the counts must be scored as many particles are culturable as possible. In this connection this study revealed that the L-J medium is not suitable medium to determine viable units in BCG vaccines regardless of vaccine strain and quality. Some investigator also noticed unacceptable disadvantages of the L-J medium in viable units counts of $B C G$ vaccines, so that they recommended silica-gel medium, which may not be applicable to all levels of tubeculosis laboratories. We, however, found that $1 \% \mathrm{KH}_{2} \mathrm{PO}_{4}$ Ogawa or KIT medium is economic and suitable, thus they can be replaced with the L-J medium.

It has been also found that, although viable units counts of domestic vaccine based on bacterial content could be graded a good quality, the viability and heat stability of them seemed to be 
somewhat inferior to the imported vaccine of same strain, suggesting that freeze-drying condition may affect viability and heat stability of bacilli to a significant extent.

\section{SUMMARY}

Viable units counts in BCG vaccine on the L-J medium, which has been most widely used, have been compared with those on the other media, $1 \% \mathrm{KH}_{2} \mathrm{PO}_{4}$ Ogawa medium, KIT medium, and $7 \mathrm{H} 11$ medium. The viable particles were counted least on the L-J medium and this medium also required much longer incubation to obtain maximum counts than the other media.

\section{REFERENCES}

1) Collins, FM: Tuberculosis. In bacterial vaccines, Academic Press Inc., 1984

2) WHO Expert Committee On Biological Standardization. Revised requirements for dried BCG vaccine. World Health Organization, Geneva, 1979

3) Oommen AV: Enumeration of viable units in $B C G$ vaccine: a comparison between Löwenstein-Jensen medium and $7 \mathrm{H} 10$ medium with silica gel. Tubercle 45:241-245, 1964

4) WHO TB Tech. Guide, 1967 